\title{
Palestine in The Western Literature
}

\author{
Jamil Yousef Al-Asmar* \\ University of Palestine,Gaza, Palestine
}

*Corresponding author: Jamil Yousef Al-Asmar, Lecturer at the University of Palestine,Gaza, Palestine

\section{Introduction}

This is a portion from an introduction meant to introduce the book I am intending to finish shortly. The book is about Palestine, where does it stand among the nations? Where is Palestine now? Who occupied Palestine now? What is the name of this country now and in the ancient time? To what extent the fabricators managed to change the name? And there are many questions concerning this issue. All of which will be under the book's title: Palestine in The Western Literature which will soon be done.

I have dug the history from the tenth millennium of its depth, and waded through its lanes and labyrinths, through its ups and downs, through its victories and defeats, through the gloomy days and years of the ages of man, through the delightful time of man all over the earth wherever man could be found, I have found only the word Palestine there through those vanished empires and not any other names to be instead of Palestine. I have paved the ways underneath the holy Bible and fond the same result; it is the land of Palestine and no any other land to substitute the old land of the Palestinians who were called aggressively 'philistines' for some hidden purpose of those gone kingdoms and empires. The word is still Palestine and will continue to be so whatever trials the occupiers to obliterate and to erase this name can be, they won't legislate the legislated since the land was peopled with Palestinians. I have turned over the thousands of historical pages of man; the conflicts, the agreements, the wars and the peace that had been once signed by rulers of those empires and states and countries along the history of human being here on this piece of land and found the same result too: the land is called Palestine and the people over this land are called the Palestinians.

Simply itis, and does notneed any complication and exaggeration of the speeches, nor it needs an intelligence, it is not puzzles and riddles of life to be solved, it is as I said, it needs no adroit men and sagacity to infer the land of Palestine, to ask in terror, nor to ask in pleasure: to who the land belongs? It is Palestine and it is for the Palestinians, paying no attention to the one who said otherwise.
Let those who said something else soak their speech and then drink its water with no hesitation. Known it is that the land never changed if once the owners become weak or sick or poor, whatever the changes may be the land will remain the same land and its people will remain its people, even if they were kicked out of their beloved country. The land won't submit to the counterfeit of the powerful, nor to the deadly trials of changing the shape and the color, but will never change the air nor the sky of Palestine which is destined to be over this land, to be over this particular piece of land the holy land of Palestine. If you ask the mountains of Palestine about the passing nations over its land the list will be so long, rather uncountable those who passed from Palestine, who were guest occupiers, who had their own land and just passed from here for a temporary period. Despite all these changes throughout the history of man over this old globe, Palestine remained Palestine and it will for sure remain so to the end of air being over this earth, and until the universal lantern be extinguished by the order of its Creator.

To be known that reality should, one day, be bright and known to others whatever the trials of those counterfeited people try to fabricate it, it is just like good original oil: It always jumps over water. Yes, when the land was empty of people, the Peninsula was full of Arabian Dynasties who used to invade and raid each other. However the defeated tribe used to move to the northern side of the Peninsulas as wayfarers and outcaste Bedwins. This was done at the dawn of history and before the ages of man on earth, for as it is said (which agreed upon) that Adam and Eve started their offsprings here in the Middle East and in particular in the Peninsula.

Palestine ever stands in history as the home land of the Palestinians who inhabited the land since the depth of time. This has been authenticated on the tongues of many of the world poets, historians, geographical, socialists, and even philosophers of the world from the ancient time such as Cornelius Tacitus (56-120 BC) a senator and historian of the Roman Empire and Ammianus Macellinus (330- 391 BC) a Roman soldier and historian and 
Piankhi (774-714 BC), and Strabo (64- 21 BC) a Greek geographical and historian as well as Ovid ( ) the Roman poet, and Giovani Boccaccio ( ) and Dante Alghieri (1256-1321) and the long list of genius people all over the world who witnessed that the land Palestine is for the Palestinians until this time in the twenty first century. So I do believe that the stories of the poets are ever the truest, from this point comes my research and the paper in which I follow now, it is the true way of finding and defending my speech before the readers. Thus comes my argument whether Palestine or Israel, supporting myself by another group of prominent English writers and authors who had deep effect on humanity such as Shakespeare, C. Dickens, Charlotte Bronte, Geoffrey Chaucer, Thomas Hardy and many others.

Hence comes the bright equation, the natural equation which needs no intelligence nor any sagacity to know that Palestine is for the Palestinians, and Britain is for the Britishners, and France is for the French people and so on all over the world; wherever you go, same is the case: the name of land is given to the inhabitants of the same land. This speech is for history but from history, this we have been learning since ever and cannot be changed by a temporary strength prevailed once upon a group of people or even a group of highway men who possess power; the land, any land cannot belong to them at any circumstance. Same is the case of Palestine, we cannot possess an ant's size to change or alter history that had been saying and will continue saying with the same tongue: That Palestine is for the Palestinians although they were obliged to leave their country at the swords edges. We all know that Israel is created by the West on the land of Palestine in (1948); it is the western make out of the already made for the Palestinians, so nobody, even the Europeans and the Americans, can make the made.

Palestine is called The Holy Land, the title and the name did not come from vacuum, but from solid authentic source and an everlasting spring that had been flowing with the hundreds of millions of people since Christianity came into being under the sun, over the land, and beside the seas and oceans. The land is there and the people are there too, the people are holding a good position in the history of human being, the people of Palestine are ever there, horning the sky and tilling the land and smelling their own lavender flowers, and the mountainous thymes and wheat fields over the history; passes from over the Earth where Palestine as a land was destined to those people who inherited it, since ever and since the sun rises and sits, no body of the civilized world could deny this fact or these facts that are going and renewing day by day along with the tombs and graves of the old land owners.

However the land does not melt or obliterated from the map if once its people became weak by time or by another force that could dominate it, yet it will stay the owners' land whatever the changes and judgment of the time could be, in any shape the land won't be lost due to an advance of an alien strangers armored with heavy weapons, this won't give the land to others, nor any power can legislate its legality to others who are ever strangers in religion, in customs and in tradition, strangers in language, strangers in their taste, in their shape, in their language, in their features, in their ideas and thoughts, in their belief and their worshipping and even in their general theological ground and even Deity. The land stands there solid and heavy with its mountains which never move from their places, for they are planted here on the land of Palestine since the people of Palestine were planted by the hand of Allah and not by the hand of temporary force or dominations, or the so-called colonization, a name I oppose to give the colonizers for they never colonize but [destronize*1] and [lootinize*] the land and its wealth as they do in the Arab World where the oil is located.

There was no period in history without the presence of the Palestinian people on this land. Even Lord Jesus was the first Palestinian to be tortured on this land, for the Romans also gave the name of Palestine to this land one hundred and thirty four years before the birth of Jesus. When the Romans gave the land the name Palestine, it was full of Palestinians and with little percentage of the Jews which would not exceed the $4 \%$ of the Palestinian population, so even before the Romans gave this name, it was not empty land, it was full of Palestinians until this moment despite the great expatriation that took place to the Palestinians in (1948) when the Jews and Zionism kicked the original owners to the rest of the world by the hearty support of the English dominators of the then land of Palestine, and now by the blind generous support of the Americans who stand on the side of oppression against the oppressed, deprived the Palestinians their own right, who look every sun-rise at their occupied land at a distance of a stone throw, this is the judgment of the civilized Europe and America!Thus, the occupiers have imported a new name for the land of Palestine, they have manufactured a new design for the land which had always been densed with its own people, generation after generation, and that according to Thomas Hardy's (1894) speech of those 'enemies' who were called the 'philistines' were the first to reside in this ancient land.

Everything in the land and on the land of Palestine says so; says that the old generations of the land since the flood of Noah and his ark that, as the people of this land believe, held on its deck Palestinians. So, whatever man tries to change the truth and change the facts, he won't be able to do that, for everything on the land is a witness of the true fulness and reality of the whole play that modern man particularly Americans and Europeans along with the

${ }^{i}[$ destronize*] and [lootinize*] are both not under the right spelling but I wanted to create a new word to suit my defence and my own taste. So thy both rhyme with 'colonize'. 
Jews try to play as to change the origin of the land, of man and of every moving object on this piece of land, which nearly talks and utters with the facts around. Here I may quote the researcher's own poem who is a poet, a lecturer, a writer and a commentator too in which he believes in the maps of the old Bible, particularly those maps were placed at the back or at the front of the bible's pages which nearly speak of the originality of the land and the people, however we may catch the lines of Prof. Dr. Jamil Yousef Al-Asmar who admits only the maps of the Bible concerning Palestine and not any other fabricated maps, his stanza goes like this:

The maps of the old Bible are ever the truest maps

Others are counterfeited, spring from Zionist laps

We, only, admit the old Biblical Canaanites deep land

And turn away fabricated ones, the land is our sand.

Somewhere we read for this Palestinian writer what ensures that the land is and was called Palestine, the writer derived his information from the most prominent English writers as we shall see down in this book. However, the new short poem goes like the following:

\section{Here I am}

Here I am supported by the English literary matchless,

Literary giants who saw only the true Palestinian land

As a land for Arab Palestinians, not deportees shoeless!

We had been and still possessing the upper legal hand.

Here, as readers, we came to know that the country Palestine was there throughout the western production, as we shall see down this book, since man knew the pen to write and the book to read, the Europeans first who knew that this country's name was Palestine for the religious relation that connects the east to the west.
CC (i) This work is licensed under Creative

To Submit Your Article Click Here: Submit Article

DOI: $10.32474 / J A A S .2020 .02 .000126$

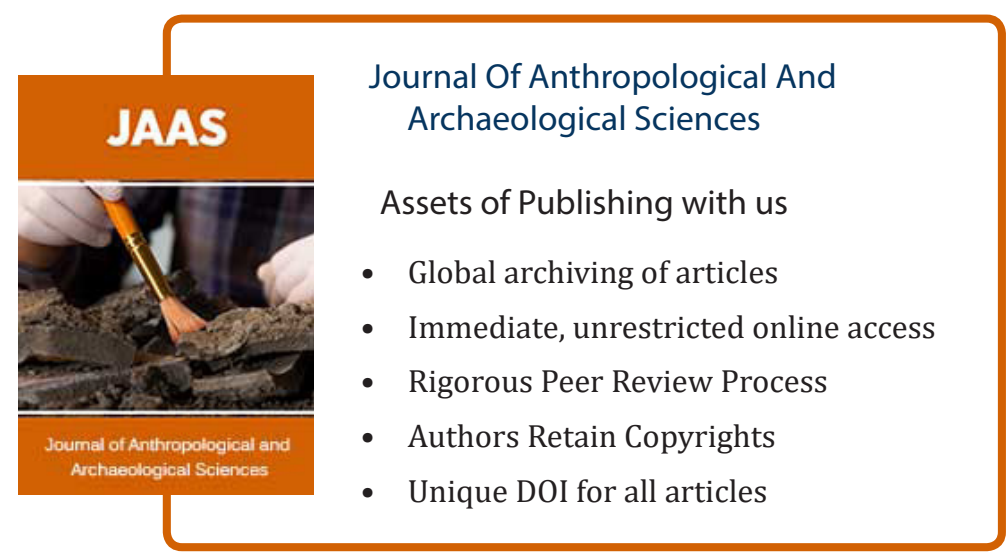

